Куртсеітов Т. Л., д-р техн. наук, професор ${ }^{1}$

Мосов С. П., д-р військ. наук, професор ${ }^{2}$

Трембовецький М. П., д-р техн. наук, професор ${ }^{3}$

$(0000-0002-5240-7131)$

Ясько В. А., канд. війск. наук, доцент ${ }^{4}$

(0000-0002-4905-083X)

1 - Національний університет оборони України імені Івана Черняховського, Київ;

2 - Національний центр управління та випробувань космічних засобів, Київ;

3 - Державний університет телекомунікацій, Київ;

4 - Кам'янець-Подільський національний університет імені Івана Огієнка, Кам’янець-Подільський

\title{
Мінна зброя у фокусі сучасних війн і збройних конфліктів
}

Резюме. У статті визначено актуальність і роль мінної зброї у форматі сучасних війн і збройних конфліктів. Встановлено, що мінна зброя продовжує залишатися важливим фактором у сучасних війнах $\mathrm{i}$ прикордонних конфліктах. Наведені конкретні приклади.

Ключові слова: міна; мінна зброя; війна; збройний конфлікт.

Постановка проблеми. Одним 3 напрямів забезпечення протидії противнику вважається, як свідчить світовий досвід сучасних війн i збройних конфліктів, застосування саме мінної зброї, що підтверджується також і досвідом ведення гібридної війни у південно-східному регіоні України. Водночас, суперечливе ставлення військових експертів до ефективності застосування мінної зброї в сучасних війнах і збройних конфліктах потребує проведення дослідження з визначенням місця і ролі мінної зброї. Ці дослідження слід вважати важливими для України, яка втягнута шостий рік у гібридну війну у південно-східному регіоні. Результати досліджень мають допомогти у визначенні перспективності застосування мінної зброї 3 урахуванням досягнень науково-технічного прогресу, зокрема для української армії з урахуванням світового досвіду та викрити проблемні питання ii застосування, зважаючи на положення Оттавської конвенції.

Аналіз останніх досліджень i публікацій. Питання, пов'язанні 3 дослідженням місця $\mathrm{i}$ ролі мінної зброї в сучасних війнах, збройних i прикордонних конфліктах розкриті у працях іноземних та вітчизняних фахівців і вчених: В. Валецького, Ю. Веремеєва, Б. Воровича, Г. Козачкова, В. Коцюруби, М. Кревельда, Т. Куртсеітова,
А. Марищенка,
В. Нероби,
О. Осадчого,

В. Рябінова,

В. Рунова,

Р. Тимошенка,

В. Фролова, В. Яська $[1-7,11,12,27-29]$.

Разом 3 тим, питання систематизації світового досвіду і визначення ролі мінної зброї в сучасних війнах і збройних конфліктах для його подальшого використання в інтересах Збройних Сил України, є новими i потребують

проведення відповідного дослідження.

Мета статті. Систематизувати світовий досвід щодо ролі мінної зброї в сучасних війнах і збройних конфліктах.

Виклад основного матеріалу. Дві світові війни, що мали місце в минулому столітті та десятки локальних війн і збройних конфліктів, які відбулися після Другої світової війни, а також війни, що тривають в Іраку та Сирії, арабо-ізраїльське протистояння тощо, здійснюють значний вплив на розвиток як воєнного мистецтва, так і на стан воєнного будівництва загалом армій багатьох держав світу, а не тільки зі складу провідних. На теперішній час армії таких провідних країн світу, як США, РФ, КНР, а також європейських країн НАТО, максимально орієнтовані на ведення крупномасштабних війн [1-3]. Як правило в таких війнах роль мінної зброї зводиться, фактично, до мінімуму, незважаючи на іiі вдосконалення навіть 3 урахуванням новітніх науковотехнічних досягнень.

Водночас, як показує дійсність, мають місце війни низької інтенсивності, до складу яких належить також гібридна війна, до якої втягнута Україна протягом вже шести років. В умовах таких воєн ракетна і авіаційна зброя масово не застосовується, а на перше місце виходить стрілецька та артилерійська зброя малих калібрів, легка бронетехніка (інколи танки) і міни.

До того ж слід зазначити, що використання мін здатне урівняти шанси воюючих сторін, а також нейтралізувати переваги противника в інших видах озброєння. Так, наприклад, під час війни в Кореї (1950 - 1953 рр.) на міни приходилося 
$38 \%$ усіх втрат танків армії США. Міни в значному ступені нейтралізували переваги американців у всіх інших видах зброї під час війни у В'єтнамі. Аналіз втрат бойової техніки, згідно 3 наведеними даними, за період з листопада 1968 р. по травень 1969 р. показав, що втрати американців на мінах склали $73 \%$ від усіх втрат танків і $78 \%$ від усіх втрат бронетранспортерів [1,4]. Основу бойових дій моджахедів в Афганістані (19791989 рр.) також, як показує досвід, складали міни $[5,6]$.

У Кувейті в 1991 р. армія Іраку створила досить потужну інженерну оборону, де міни грали важливу роль. В очікуванні наступу військ коаліції іракська армія встановила уздовж кордону Кувейту із Саудівською Аравією майже 2 млн різнотипних мін. Головна полоса оборони іракських військ мала глибину 15-30 км. Полоса забезпечення (глибина 2-17 км) включала опорні пункти піхотних i танкових підрозділів, розвинену систему інженерних загороджень (дротяні загородження, протитанкові та протипіхотні мінні поля тощо) [7]. Значні втрати в танках багатонаціональних сил в Іраку були обумовлені їх підривами саме на мінах. Так, у перший день наступу після тривалого за часом авіаційного етапу операції багатонаціональних сил (38 діб), 6-а дивізія морської піхоти США тільки на мінах втратила 11 од. військової техніки, у тому числі 7 танків, а також 14 солдат [1].

Під час грузино-абхазького збройного конфлікту 1992-1993 pp. протипіхотні натискні міни фугасної дії використовувалися грузинськими й абхазькими військами в мінних полях як самостійно, так і в інтересах забезпечення протитанкових мін біля м. Сухумі та по правому берегу р. Інгурі на території Гальського району.

Мінно-вибухові пристрої (далі - МВП) активно використовувалися чеченськими збройними формуваннями під час бойових дій проти російських військ у Чечні, особливо під час розвідувально-диверсійних дій. Так, під час першої війни в Чечні (1994-1996рр.) за весь період бойових дій відбулося 217 підривів на МВП особового складу та техніки внутрішніх військ МВС РФ, унаслідок яких загинуло 105 осіб, було поранено 478 осіб і втрачено (виведено 3 ладу) 93 од. військової техніки [1].

Також 3 боку чеченських збройних формувань застосовувалися керовані та некеровані протипіхотні осколкові фугаси, створені як на основі артилерійських снарядів, мінометних мін, протитанкових мін, авіабомб, так і зарядів, що підсилювалися камінням, цеглою, шматками заліза тощо.

Найбільші втрати російські силові підрозділи, що дислокувалися в гірських районах Чечні під час другої війни у Чечні (1996 - 2006 рр.), несли через вибухи на мінних полях, встановлених військовими під час першої чеченської кампанії для захисту місць своїх тимчасових дислокацій від нападів 3 боку чеченських збройних формувань. Більшість цих мінних полів, розкиданих по всій території республіки, російські військові самі заклали без обов'язкових для них карт встановлення вибухових пристроїв [8].

3 огляду на аналіз, у 2002 p. $51 \%$ бойових втрат російських військ склали підриви на мінах, 3 них $17 \%$ - незворотні втрати [1]. За період жовтень 2002 р. - лютий 2003 р. тільки 42-а мотострілецька дивізія МО РФ втратила вбитими і пораненими близько 200 військовослужбовців. Більшість 3 них постраждали в результаті мінно-підривної діяльності на території м. Грозного [9].

За період проведення другої чеченської компанії жертвами мінної війни стали 696 осіб, а 2349 осіб отримали поранення. Більшість 3 числа загиблих склали некомбатанти - жінки та діти: загинуло 99 жінок, поранено 572 жінки; загинуло 130 дітей, поранено 616 дітей [10].

Бойові дії, що відбувалися у свій час на території колишньої Югославії (1991 1995 pp. - у Словенії, Боснії і Герцеговині; 1988 - 2002 pp. - у Косметі, Південній Сербії та Македонії), показали, що міни та фугаси відіграють значну роль у бойових діях, а в низці випадків вона була домінуючою. Так, рівень втрат під час бойових дій у Хорватії (1991 - 1992 рр.) від мін досягав 30 \% [11].

У період другої війні в Іраку (2003 2011 рр.) головну роль у захисті проти військ США та Великої Британії відігравало застосування мін. Завдяки світовим засобам масової інформації та пропаганди іракське командування заздалегідь отримало інформацію не тільки про склад сил і засобів 3 боку нападаючих, але й основні напрями наступу. Це дало змогу підготувати потужну оборону, в тому числі завдяки масовим мінним загородженням. Іракці підготували на переважній більшості напрямів великі протитанкові мінні поля. Мінними полями вони також оточили опорні пункти та вузли опору.

Унаслідок застосування саморобних вибухових пристроїв з боку іракців коаліційні 
війська понесли значні втрати - $50 \%$ від загальної чисельності вбитих і поранених. Із загального числа втрачених коаліцією танків та інших бронемашин $25 \%$ прийшлось на міни $[4,12]$.

Не стали виключенням бойові дії в Сирії (з 2011 р.): з боку сірійської армії, як і з боку бойовиків, активно застосовувалося мінування. Мінна війна стала складовою бойових дій в Сирії. Так, Сирійська Арабська армія широко застосовувала протипіхотні та протитанкові міни [12, 13].

Мінна війна не стала виключенням і на кордонах. Так, у 2017 р. влада М'янми прийняла рішення про встановлення мін на кордоні з Бангладеш, ймовірно, щоб не дати повернутися представникам народності рохінджа, які втекли у свій час із країни [14].

Під час вірмено-азербайджанського протистояння вірменська сторона у військових цілях використовує протипіхотні та протитанкові міни. На лінії зіткнення військ і вдовж вірмено-азербайджанського кордону відбувається щільне мінування. Водночас азербайджанською стороною незаконно мінувалася територія Грузії з тією метою, щоб вірменські групи не заходили з боку кордону Грузії на їх територію $[15,16]$.

Проблемним 3 позиції мінної обстановки залишається кордон між Таджикистаном i Узбекистаном. Міни на таджицько-узбецькому кордоні були встановлені в односторонньому порядку 3 узбецької сторони на початку 2000 -х років унаслідок загострення відносин між двома державами. На той час з боку Ташкента така ініціатива обгрунтовувалася необхідністю захисту кордону від бойовиків-ісламістів. Як свідчить статистика, тільки за 18 років на мінах підірвалося майже 800 законослухняних мирних громадян - некомбатанти, 3 яких 474 людини загинули, зокрема жінки і діти $[17,18]$.

Мінування гірських районів таджицькоузбецького кордону почалося в 1999 р., після спроби прориву до Сурхандар'їнської області Узбекистану групи бойовиків Ісламського руху Узбекистану (далі - IPУ) 3 Таджикистану. Бойовики IPУ базувалися в Афганістані, а важкодоступні гірські райони Таджикистану використовували як плацдарм для нападів. Ташкент звинувачував сусідів, а таджицькі пастухи $\mathrm{i}$ селяни регулярно підривалися на безладно встановлених протипіхотних мінах.

Державні кордони між двома республіками узгоджені та врегульовані на
$90 \%$, але залишаються найскладніші райони та мінні поля, що потребують значних ресурсів i часу. Смертельно небезпечними залишаються 54 ділянки прикордонної території, близько 11 тисяч мін (для порівняння, на таджицько-афганському кордоні закладено до 220 тисяч мін). Починаючи 32018 р. сторони приступили до розмінування кордону [19].

Тривалий час залишався замінованим кордон між Південною Кореєю і Північною Кореєю. У демілітаризованій зоні знаходилося декілька десятків тисяч мін [20,21].

Гібридна війна, що триває у південносхідному регіоні України з 2014 р. не стала виключенням у застосуванні мінної зброї. Відповідно до даних МО України, на сході країни унаслідок підриву на мінах та інших вибухонебезпечних залишках війни з 2014 p. постраждало 833 цивільні особи, 3 яких 269 осіб загинуло, інші зазнали поранень і каліцтва. 3 поміж згаданих жертв - 27, тобто кожна десята, це діти [22]. Унаслідок підриву на мінах і вибухових пристроях у зоні збройного конфлікту тільки за три місяці 2017 р. загинуло понад три десятки цивільних, кількість поранених перевищило півтори сотні людей. Міни та вибухові пристрої розкидані по всій території конфліктної зони, особливо уздовж лінії бойового зіткнення і являють собою серйозну загрозу для цивільних осіб, включаючи дітей. Це на $70 \%$ більше, ніж за такий же період 2016 р. [23].

За даними $\mathrm{OOH}$, тільки 3 січня по вересень 2017 р. у зоні бойових дій від мін загинуло і поранено 103 особи [24]. Протягом 2018 р. в окремих районах Донецької i Луганської областей, тимчасово непідконтрольних уряду України, і в “сірій” зоні було зафіксовано 65 підривів військовослужбовців на мінах, унаслідок яких загинуло 25 осіб. Крім того поранення отримали 84 особи, серед яких були також сапери [25]. 2019 рік і початок 2020 не стали виключенням.

Україна в 2016 p. випередила за кількістю жертв підриву на мінах такі гарячі точки, як Афганістан, Сирія, Смен та ін. Міни вбили і скалічили майже 2 тис. осіб $[12,26]$. За даними міжнародної неурядової організація Handicap International Україна залишається в "лідерах" за кількістю загиблих на мінах і МВП. За оцінками іноземних експертів наша країна станом на 2019 р. знаходилася на п'ятому місці у світі в рейтингу країн 3 найвищою кількістю жертв цього різновиду 
боєприпасів. Перше місце у цьому списку посідає Афганістан [27].

Як показує аналіз, наприкінці XX ст. було виявлено дві особливості щодо мінної війни. Перша полягає в тому, що традиційні міни, які встановлюються вручну або засобами механізації, не тільки не втратили своїх позицій, але стали більш досконалими i такими, що складно виявляються. До них додалися дистанційно встановлювані міни, що роблять мінну війну більш динамічною i такою, що вписується в сучасну маневрену війну. Разом узяті, ці дві категорії мін зробили мінну війну більш привабливою як для регулярних армій, так i для іррегулярних збройних формувань.

Друга особливість виявилася в значному відставанні засобів протимінної боротьби, входженні їх у стан затяжної системної кризи, що теж зробило мінну війну ще більш привабливою. На теперішній час немає жодного скільки-небудь надійного засобу пошуку мін. Навіть раніше абсолютно бездоганний спосіб пошуку за допомогою примітивного щупу на тлі неконтактних датчиків цілі (сейсмічних, геофонних, інфрачервоних, радіолокаційних) стає абсолютно незадовільним: міна не дає можливості наблизитися до неї. Разом 3 тим, міни не завжди знаходяться тільки на мінному полі, бо їх часто ставлять, використовуючи засоби маскування, у стороні від нього.

Аналіз досвіду застосування мін у локальних війнах i збройних конфліктах, a також у прикордонних конфліктах показує, що мінній боротьбі притаманна низка характерних рис: замість протяжних мінних полів зазвичай ставлять невеликі групи мін i навіть окремі міни (останне особливо характерно для мін-фугасів і мін-пасток); ці мінні групи й окремі міни найчастіше ставлять безсистемно, дуже часто - безграмотно; захоплюються установкою керованих мін (зокрема фугасів і пасток); мінні поля, групи мін, а тим більше окремі міни прикривають вогнем; встановлені мінні групи і поля не фіксують у документах; використовується величезна кількість мін, детонаторів і вибухових речовин кустарного та напівкустарного виготовлення, небезпечних у виробництві i застосуванні для самих виробників [1, 4, 12, 28-30].

Отже, для сучасного періоду властиво, 3 одного боку, поява нових, технічно складних i вельми досконалих мін, а 3 іншого боку величезне збільшення номенклатури примітивних мін, що активно застосовуються в умовах партизанської, напівпартизанської та гібридної війн, а також на кордонах конфліктуючих держав.

Мінна війна залишається одним 3 основних способів партизанської боротьби. Міни у поєднанні зі штучними та природними перешкодами i прикриттям їх стрілецьким вогнем і засобами вогневої підтримки забезпечують стримування переважаючих сил противника. Так, під час війни у В’єтнамі Армія визволення Південного В'єтнаму за допомогою мін змогла звести до нуля технічну перевагу американської армії. Після цього війна найрозвиненішої у військовотехнічному відношенні армії світу 3 противником, у якого переважала лише стрілецька зброя, пішла фактично на рівних. Як наслідок, США зазнали нищівної поразки, якої вони ніколи не знали в своїй історії [12].

Спостерігається також гнучка зміна тактики незаконних збройних формувань (далі-НЗФ) 3 мінування місцевості та доріг, застосування МВП різного принципу дії залежно від характеру дій військ, порядку руху військових колон i тактики дій інженерних підрозділів 3 перевірки на мінування шляхів руху військ, місцевості й об'єктів. Розповсюджені нестандартні, специфічні способи протидії військам, що характеризуються скритністю, раптовістю і підступністю, широким застосуванням воєнної хитрості.

Прийняттям у 1997 р. "Конвенції про заборону застосування, накопичення запасів, виробництво і передачу протипіхотних мін та про їх знищення" [30] переслідувалася мета щодо позбавлення людства від одного 3 видів смертоносної зброї - мін. Водночас, Оттавська конвенція стала потужним поштовхом до нового вітку в розвитку мінної зброї, переведення ii на якісно новий рівень. Насамперед, це обумовлено недостатньою конструктивністю самого документа, що залишило багато “білих плям”, які дають змогу державам, які мають достатні фінансові ресурси, розробляти та приймати на озброєння міни, які мають набагато більші вражаючі властивості, є більш чутливими, i здатні самостійно вибирати ціль і вражати пі в найвигідніший момент. Таким прикладом може служити поява, так званих, “інтелектуальних" мін, що мають кілька боєголовок і встановлюються 3 БПЛА. До їх завдання належить виявлення танків противника 3 відстані в кілька кілометрів, впізнавання їx i, запускаючи по черзі боєголовки, ураження цих танків ударним 
ядром у корпус або вежу (найбільш вразливі місця), контролювання ураження цілі i, у разі необхідності, ऑiі повне знищення. Одна така міна, за прогнозами фахівців, зможе забезпечувати контроль площі в кілька квадратних кілометрів [4, 31].

Під час війни у південно-східному регіоні України з боку противника проти українських військових регулярно використовуються БПЛА зі встановленими на них мінами і бомбами.

Особливістю мінної боротьби $є$ те, що сучасні зразки мін цілком забезпечують можливість, за порівняно невеликих витрат власних сил і засобів, знизити темпи наступу противника (агресора), нанести йому досить істотних втрат. Так, німецька міна "PARM 2" призначена для захисту території від бронетанкових армад противника і по суті являє собою автоматичний гранатомет, що метає оперену кумулятивну гранату діаметром 128 мм на відстані до 40 метрів. Міна "PARM 2" встановлена на невисоку триногу i може обертатися по горизонталі на $360^{\circ}$, а по вертикалі - від $45^{\circ}$ до 90․ Мікропроцесор обчислює “ідеальний” момент пострілу. За твердженням військових фахівців, боєприпас вибухає всередині броньованої машини і не несе будь-якої небезпеки для піхоти [32].

Іншим прикладом $\epsilon$ розробки російських фахівців, які створили противертольотні міни, які автоматично стріляють по вертольотах противника кумулятивними снарядами. Виявити таку міну за допомогою радіолокаційних засобів неможливо, що робить ऑiі смертельно небезпечною для вертольотів. На відстані приблизно 1 км акустична система виявляє шум гвинтокрилої машини, а потім багаточастотний інфрачервоний датчик забезпечує точне націлювання i, якщо ціль знаходиться в зоні 150 м від бойової частини міни, відбувається постріл.

У американців знаходиться на озброєнні міна M86 від переслідування, яка зазначена як боєприпас, щоб формально не порушувати умови Оттавської конвенції. Зазначений боєприпас призначений для затримки наступаючого противника в умовах бою, коли доводиться спішно залишати позиції. Через 25 сек. після установки 3 нього викидаються до семи розтяжок довжиною 6 м. Якщо солдат противника зачіпає один 3 тросів, боєприпас, подібно ракеті, спрямовується вгору і на висоті 8 футів (приблизно 2,5 м) вибухає, вражаючи навколо осколками [33].

За прогнозами експертів, міни з пасивних боєприпасів стрімко перетворюються на зброю особливого роду, що у перспективі призведе до ситуації, коли замість армії оборону держави здійснюватимуть "інтелектуальні мінні поля" типу IMF (США), DAVID (Німеччина), а також міни 3 широкою зоною ураження - типу М93 "Хорнет" (США).

Таким чином, мінна зброя продовжує залишатися важливим фактором у сучасних війнах i прикордонних конфліктах, якісно змінюючись під впливом науково-технічного прогресу.

Висновки. Унаслідок проведеного дослідження визначена актуальність і роль мінної зброї. Доведено, що мінна зброя продовжує залишатися важливим фактором у сучасних війнах і прикордонних конфліктах. На конкретних прикладах показано, що використання мін у війнах низької інтенсивності, до складу яких відноситься також гібридна війна, до якої втягнута Україна протягом шести років, здатне урівняти шанси воюючих сторін, а також нейтралізувати переваги противника в інших видах озброєння.

Подальші дослідження мають відбуватися за такими актуальними напрямами: дослідження стану світової проблеми розмінування; дослідження сучасних підходів до виявлення мін із застосуванням роботизованих комплексів, зокрема безпілотних літальних апаратів; розробка класифікації мін, як об'єктів виявлення за допомогою безпілотних літальних апаратів; дослідження розпізнавальних ознак мін на цифрових аерознімках тощо.

Подяка. Дослідження проведені за підтримкою НАН України в межах Цільової науково-технічної програми оборонних досліджень НАН України 2020 року.

\section{СПИСОК ВИКОРИСТАНОЇ ЛІТЕРАТУРИ}

1. Валецкий O. В. Минное оружие: вопросы минирования и разминирования. Москва : Крафт, 2009. $576 \mathrm{c}$.

2. Тенденції розвитку форм і способів збройної боротьби у сучасних локальних війнах і збройних конфліктах : кол. монографія / П. П. Ткачук, С. П. Мосов, О. П. Красюк, О. В. Левченко, О.Л.Гапеєва. Львів : HACB, 2015. $90 \mathrm{c}$.

3. Куртсеітов Т. Л., Нероба В. Р. Прихована загроза. Оборонний вісник. 2019. № 10. С. 18-23.

4. Веремеев Ю. Г. Мины вчера, сегодня, завтра. Минск : Современная школа, 2008. 352 с.

5. Сухолесский А. В., Мусиенко А. В. Спецназ ГРУ в Афганистане 1979 - 1989. Москва : Русская панорама, 2012. $138 \mathrm{c}$.

6. Рунов В. Афганская война. Все боевые операции. Москва : Эксмо, Яуза, 2014. 432 с.

7. Корж Г. Саддам Хусейн. История взлета и падения. Москва : АСТ, Фоліо, 2004. 479 с.

8. Боевики варьируют тактику минной войны в Чечне. URL: http://www.fsb.ru/fsb/comment/ufsb/ single.htm\%21id\%3D10311240\%40fsbComment.html (дата звернення: 03.05.2020).

9. Потери российских военных в Чечне - официальные и неофициальные данные. URL: https://www.svoboda.org/ $\mathrm{a} / 24185620 . \mathrm{html}$ (дата звернення: 03.05.2020). 
10. Почти 700 человек стали жертвами “минной войны” в Чечне. URL: https://www.newsru.com/russia/ 06apr2006/miny.html (дата звернення: 03.05.2020).

11. Валецкий О. В. Югославская война $1991-1995$ гг. Москва : Крафт, 2008. 528 с.

12. Марищенко А. Т. Особенности устройства заграждений и производства разрушений в локальных войнах и вооружённых конфликтах. Москва : Военноинженерный университет, 2001. 18 c.

13. Мины в Сирии. URL: http://csef.ru/ru/oborona-ibezopasnost/505/ miny-v-sirii-7163 (дата звернення: 03.05.2020).

14. Мьянма ставит мины на границе с Бангладеш, чтобы беженцы не могли вернуться. URL: https://news.rambler.ru/other/37811522-myanma-miniruetgranitsu-s-bangladesh-dlya-zaschity-ot-bezhentsev/ (дата звернення: 03.05.2020).

15. Грузия и Армения вновь подняли вопрос делимитации границы. URL: https://sputnikgeorgia.ru/politics/20160802/232886821.html (дата звернення: 03.05.2020).

16. США финансируют минирование азербайджанских территорий Арменией - факты и цифры. URL: https://novosti.az/politics/13182.html (дата звернення: 03.05.2020).

17. Саперы приступят к разминированию таджикскоузбекской государственной границы в мае 2018 года. URL: https://tj.sputniknews.ru/analytics/20180419/ 1025353719/ bezopasnyy-rubezh-kak-razminirovaniyetajiksko-uzbekskoy-granitsy.html (дата звернення: 03.05.2020).

18. Освобождая Таджикистан от мин. URL: https://www.osce.org/ru /secretariat/25761?download=true (дата звернення: 03.05.2020).

19. Северная Корея начала ликвидировать мины на границе с Южной Кореей. URL: http://frontnews.eu/ news/ru/40847/ (дата звернення: 03.05.2020).

20. На границе Северной Кореи и Южной Кореи убирают мины. URL: https://www.caravan.kz/news/nagranice-severnojj-korei-i-yuzhnojj-korei-ubirayut-miny484788/ (дата звернення: 03.05.2020).

21. Мінна загроза: щодесята жертва підривів - дитина. URL: http://www.mil.gov.ua/news/2019/02/06/minna- zagroza-shhodesyata-zhertva-pidriviv-ditina/

(дата звернення: 03.05.2020).

22. В Совбезе ООН озвучили ситуацию по жертвам от подрыва на минах на Донбассе. URL: https://dnews.dn.ua/news/618555 (дата звернення: 03.05.2020).

23. ООН: Україна на першому місці за кількістю смертей від вибухів мін. URL: https://www.pravda.com.ua/news/ 2017/12/5/7164284/ (дата звернення: 03.05.2020).

24. За рік на Донбасі через міни загинули 25 бійців. URL: https://ua.korrespondent.net/ukraine/4053062-za-rikna-donbasi-cherez-miny-zahynuly-25-biitsiv (дата звернення: 03.05.2020).

25. ООН: Украина с 2016 г. опередила по числу жертв подрыва на минах Афганистан, Сирию и Йемен. URL: https://diana-mihailova.livejournal.com/3258041.html (дата звернення: 03.05.2020).

26. Україна - серед лідерів у світі за кількістю жертв мін. URL: https://www.dw.com/uk/україна-серед-лідерів-усвіті-за-кількістю-жертв-мін/ a-51353586 (дата звернення: 03.05.2020).

27. Петров М. Мины в современной войне. URL: http://cripo.com.ua/ likbez/?p=210036/ (дата звернення: 03.05.2020).

28. Рябинов В. О разработке комплекса мероприятий по противодействию минной войне. Армейский сборник. 2013. № 1. C.39-42.

29. Валецкий В. О. Оружие современных войн: боеприпасы, системы управляемого вооружения и меры противодействия их применению. Пушкино : Центр стратегической конъюнктуры, 2015. 264 с.

30. Оттавська конвенція. URL: https://uk.wikipedia.org /wiki/оттавська__ конвенція (дата звернення: 03.05.2020).

31. "Умные" мины: что важно знать об оружии XXI века. URL: https://russian7.ru/post/umnye-miny-chto-vazhnoznat-ob-oruzhii/ (дата звернення: 03.05.2020).

32. PARM 2 German Mines. URL: http://www.pmulcahy.com/mines/ german_mines.html (дата звернення: 03.05.2020).

33. M86 Pursuit Deterrent Munition. URL: https://en.wikipedia.org/ wiki/M86_Pursuit_Deterrent_Munition\#cite_noteM86ref2-1 (дата звернення: 03.05.2020).

Стаття надійшла до редакційної колегії 29.05.2020

\section{Mine weapons in the focus of modern wars and armed conflicts}

\section{Annotation}

According to the results of the research, the relevance and role of mine weapons in the format of modern wars and armed conflicts are determined. It has been established that mine weapons is still an important factor in modern wars and border conflicts. At the specific examples it is shown that the use of mines can equalize the chances of the warring parties, as well as neutralize the enemy's advantages in other weapons. It is determined that the modern period is characterized, on the one hand, by the appearance of new, technically complex and perfect mines, and on the other hand a huge increase in the range of primitive mines, which are actively used in guerrilla, hybrid wars and on the borders of conflicting sides.

It is established that the peculiarity of mine action is that modern models of mines fully provide the opportunity, at a relatively low cost of their own forces and resources, to reduce the rate of attack of the aggressor and inflict significant losses to him. The paper focuses on the use of so-called "intelligent" mines in modern conditions and the possibility of their installation on unmanned aerial vehicles.

Further research should take place in the following relevant areas:

study of the state of the world problem of demining;

study of modern approaches to mine detection with the use of robotic systems, including unmanned aerial vehicles;

development of classification of mines as objects of detection by means of unmanned aerial vehicles; study of mine identification features on digital aerial photographs, etc.

Keywords: mine; mines weapon; warfare; armed conflict. 